\title{
Genetic and Environmental Influences on Digital Dermatoglyphics in Congenital Rubella
}

\author{
S. G. Purvis-Smith ${ }^{[16]}$ and Margaret A. Menser \\ Children's Medical Research Foundation, Royal Alexandra Hospital for Children, Camperdown, Australia
}

\section{Extract}

The frequency of digital patterns (whorls, ulnar loops, radial loops, and arches) was studied in 120 congenital rubella patients, in their mothers, and in 79 of their fathers. Comparison of the patients with control subjects (250 males and 250 females) showed a significant excess of whorls in the patients $(P<0.0005)$. In the control subjects, males showed a slight excess of whorls, and females a significant excess of arches $(P<$ 0.01 ); in the patients these sex differences were markedly accentuated (whorls, $P<$ 0.0005 ; arches, $P<0.0005$ ). When the parents were studied, it was found that the mothers did not differ significantly from controls but that the fathers had a raised whorl frequency $(P<0.0005)$. However, the patients had a higher whorl frequency than either their mothers or their fathers $(P<0.0005)$, which suggests that this high whorl frequency could be attributed to direct teratogenesis. The 79 available parental pairs were divided into high whorl parents (HWP) and low whorl parents (LWP); the affected children of HWP had significantly more whorls than children of LWP $(P$ $<0.0005)$, which suggests that there was an underlying inherited component in digital whorl determination.

\section{Speculation}

Although high whorl frequencies have been reported in congenital rubella, the relative contributions of genetic and viral influences and the apparent dominance of the latter have not been elucidated previously; the demonstration of a raised whorl frequency in the fathers and the observation of accentuated sex differences in the patients may be relevant to the understanding of viral embryopathy.

\section{Introduction}

Although dermatoglyphic anomalies in patients with rubella embryopathy have been reported in several studies $[1,2,11,12]$, the mechanisms causing the anomalies were not clear. This study, which includes the parents of patients with congenital rubella, aims to clarify the roles of viral and genetic influences in the aetiology of dermatoglyphic anomalies in rubella embryopathy.

\section{Subjects and Methods}

The finger and palm prints of 120 patients with rubella embryopathy were recorded together with the prints of each of their mothers and 79 of their fathers; the subjects thus included 79 parental pairs. In addition, 35 siblings were available from 21 of these 79 families. Rubella-affected patients included 43 of the group of young adult victims of the 1940 epidemic $[5,12] 32$ children from an earlier study [11], and 45 children 
Table I. Digital pattern frequency in normal control subjects, congenital rubella patients, and their parents

\begin{tabular}{llllll}
\hline & \multicolumn{5}{c}{ Digital patterns } \\
\cline { 2 - 6 } & \multicolumn{1}{c}{ Whorls } & \multicolumn{1}{c}{ Ulnar loops } & Radial loops & Arches \\
\hline $\begin{array}{c}\text { Control subjects } \\
\text { Male (250)' }\end{array}$ & $670(27 \%)$ & $1579(63 \%)$ & $142(6 \%)$ & $109(4 \%)$ \\
$\quad$ Female (250) & $617(25 \%)$ & $1614(64.5 \%)$ & $119(5 \%)$ & $150(6 \%)$ \\
Patients & & & & & \\
$\quad$ Male (64) & $330(51.5 \%)$ & $284(44 \%)$ & $24(4 \%)$ & $2(0.3 \%)$ \\
$\quad$ Female (56) & $215(38 \%)$ & $306(55 \%)$ & $21(4 \%)$ & $18(3 \%)$ \\
& & & & & \\
Mothers (120) & $262(22 \%)$ & $787(65.5 \%)$ & $64(5 \%)$ & $87(7 \%)$ \\
Fathers (79) & $267(34 \%)$ & $468(59 \%)$ & $38(5 \%)$ & $17(2 \%)$ \\
\hline
\end{tabular}

1 Number of subjects appears within parentheses.

new to this study diagnosed according to the same criteria. Testing of the adult and child patients for homogeneity before the two groups were pooled revealed no significant differences. Control prints were recorded from 500 randomly selected normal children and adults. All subjects were of Caucasian origin. The prints were recorded by one or other of the inkless techniques described previously [9].

Because elevation of digital whorl pattern frequency appears to be the most consistent and significant of the dermatoglyphic changes in congenital rubella $[2,11$, 12], this variable was selected for detailed examination. A whorl pattern was defined according to the Galton system as a dermal ridge pattern with at least two associated triradii which includes patterns with spiral, concentric, and double loop configurations [3]. Statistical analysis of whorl frequency differences was carried out using the chi-square test on a 2 by 2 classification of the data, e.g., whorls versus no whorls in patients versus controls, and statistical significance was recognized where $P$ was less than 0.01 . Although unusual palmar creases have increased incidence in congenital rubella, they were considered less appropriate for quantitative analysis in the context of this study because of their relatively lower frequency.

\section{Results}

The distribution of each sex in the control, patient, and parent groups, and the frequency of digital pattern types in these subjects is shown in Table I. Comparison of pattern frequencies (Table II) between male and female control subjects revealed the type of sex differences usually found in normal individuals, namely excess whorl patterns in the males and excess arches in the females, although only the difference in arch frequency was statistically significant $(P<0.01)$. Comparison of pattern frequencies in male and female patients showed highly significant differences, males again having excess whorl patterns $(P<0.0005)$ and females having excess arches $(P<0.0005)$. It thus appears that the normal sex differences are accentuated in rubella-affected patients.

In order to ascertain whether the patients are con-

Table II. Comparisons of digital pattern frequencies in control subjects, congenital rubella patients, and their parents

\begin{tabular}{|c|c|c|c|c|c|}
\hline \multirow{2}{*}{ Comparisons } & \multicolumn{4}{|c|}{ Significance $(P<)^{1}$} & \multirow{2}{*}{ Comment } \\
\hline & Whorls & Ulnar loops & Radial loops & Arches & \\
\hline $\begin{array}{l}\text { Control subjects: males } \\
\text { vs females }\end{array}$ & $\mathrm{NS}^{2}$ & NS & NS & 0.01 & $\begin{array}{l}\text { Normal sex differences. Males had excess whorls } \\
\text { (NS). Females had excess arches. }\end{array}$ \\
\hline $\begin{array}{l}\text { Patients: males vs fe- } \\
\text { males }\end{array}$ & 0.0005 & 0.0005 & NS & 0.0005 & $\begin{array}{l}\text { Normal sex differences accentuated. Whorls in- } \\
\text { creased in males, loops and arches decreased. }\end{array}$ \\
\hline $\begin{array}{l}\text { Males: Patients } v s \text { con- } \\
\quad \text { trol subjects }\end{array}$ & 0.0005 & 0.0005 & NS & 0.0005 & $\begin{array}{l}\text { Whorls increased in patients, loops and arches de- } \\
\text { creased. }\end{array}$ \\
\hline $\begin{array}{l}\text { Females: patients vs } \\
\text { control subjects }\end{array}$ & 0.0005 & 0.0005 & NS & 0.01 & $\begin{array}{l}\text { Whorls increased in parients, loops and arches de- } \\
\text { creased. }\end{array}$ \\
\hline $\begin{array}{l}\text { Mothers } v s \text { female con- } \\
\text { trol subjects }\end{array}$ & NS & NS & NS & NS & Whorls slightly decreased in mothers (NS). \\
\hline $\begin{array}{l}\text { Fathers vs male control } \\
\text { subjects }\end{array}$ & 0.0005 & NS & NS & 0.005 & $\begin{array}{l}\text { Whorls increased in fathers with decrease in ulnar } \\
\text { loops and arches. }\end{array}$ \\
\hline
\end{tabular}

${ }^{1}$ Significance based on chi-square test.

2 NS : Not significant. 
Table III. Comparisons of whorl frequency in parents, patients, and control subjects

\begin{tabular}{lcc}
\hline \multicolumn{1}{c}{ Comparison } & Whorl number & $P<$ \\
\hline 79 Parental pairs (158 parents) & 444 & NS $^{1}$ \\
vs & 1,287 & \\
500 Control subjects & 215 & \\
$\begin{array}{l}56 \text { Female patients } \\
\text { vs }\end{array}$ & 262 & 0.0005 \\
$\begin{array}{l}120 \text { Mothers } \\
64 \text { Male patients } \\
\text { vs }\end{array}$ & 330 & \\
79 Fathers & 267 & 0.0005 \\
79 Parental pairs (158 parents) \\
vs
\end{tabular}

1 NS : Not significant.

sistent with the congenital rubella patients described previously, and whether the parental groups are typical of a normal population, the test subjects were compared statistically with normal controls (Table II). The rubella patients had highly significant elevations in whorl pattern frequency, but their mothers did not differ significantly from control subjects with respect to the four digital pattern types (whorls, ulnar loops, radial loops, and arches); the fathers showed a highly significant elevation in the frequency of whorl patterns $(P<0.0005)$. Despite this elevation in the fathers alone, whorl numbers in the 158 mothers and fathers combined in the 79 parental pairs did not differ significantly from normal whorl numbers in 500 control subjects (Table III).

The major trend noted in the foregoing comparisons was increased digital pattern complexity (increased whorl frequency) in patients and in their fathers; whorl frequencies, therefore, merited closer scrutiny. Separate comparisons (Table III) of rubella patients with their mothers, with their fathers, and with the parental pairs, showed in each case a significantly higher whorl frequency in the patients. It should be noted that these patient-parent differences indicate an environmental influence on whorl development in the patients and that in the patient-father comparison the difference is significant in spite of the increased paternal whorl frequency. Further evidence of environmental influence was provided by testing ( $t$ test) the significance of midparent-patient and midparentsibling correlation. Correlation between midparents and unaffected siblings was highly significant $(P<$
0.001 ), but the correlation between midparents and patients did not achieve significance $(0.05<P<0.1)$.

Study of genetic factors in determining whorl frequency in the patients is facilitated by arbitrary subdivision of the 79 parental pairs into high whorl parents (HWP) and low whorl parents (LWP). Those pairs of parents (32 pairs) with a mean whorl count (midparental value) of greater than 3 are classified as HWP, and those pairs (47 pairs) with a mean equal to or less than 3 are classified as LWP; the two parental groups thus created are different in whorl frequency, the HWP having significantly more whorls than control subjects while the LWP have significantly less than the same control subjects (Table IV). On the basis of this arbitrary division in the parents, comparison of whorl frequency in the rubella children of HWP with the frequency in the children of LWP shows that there is a significantly higher frequency in the children of HWP, i.e., high whorl parents tend to have high whorl children and low whorl parents tend to have low whorl children. This similarity between parents and their children suggests a genetic influence on whorl development.

Environmental influence on whorl development mentioned previously is confirmed by group comparisons of HWP and LWP with their respective children;

Table $I V$. Comparisons of whorl frequency in high whorl parents (HWP), low whorl parents (LWP), their affected children, and control subjects

\begin{tabular}{|c|c|c|c|}
\hline Comparison & $\begin{array}{l}\text { Whorl } \\
\text { number }\end{array}$ & $P<$ & Comment \\
\hline $\begin{array}{l}64 \text { HWP (32 pairs) } \\
\text { zs } \\
500 \text { Control subjects }\end{array}$ & 1,287 & 0.0005 & $\begin{array}{l}\text { Excess whorls in high whorl par- } \\
\text { ents, compared with control } \\
\text { subjects. }\end{array}$ \\
\hline $\begin{array}{l}94 \text { LWP (47 pairs) } \\
\text { vs } \\
500 \text { Control subjects }\end{array}$ & 1,287 & 0.0005 & $\begin{array}{l}\text { Decreased whorls in low whorl } \\
\text { parents, compared with con- } \\
\text { trol subjects. }\end{array}$ \\
\hline $\begin{array}{l}32 \text { Children of HWP } \\
\text { vs } \\
47 \text { Children of LWP }\end{array}$ & $\begin{array}{l}200 \\
159\end{array}$ & 0.0005 & $\begin{array}{l}\text { Excess whorls in children of high } \\
\text { whorl parents, compared with } \\
\text { children of low whorl parents }\end{array}$ \\
\hline $\begin{array}{l}32 \text { Children of HWP } \\
\text { vs } \\
64 \text { HWP ( } 32 \text { pairs) }\end{array}$ & 303 & 0.0005 & $\begin{array}{l}\text { Excess whorls in children, com- } \\
\text { pared with high whorl parents. }\end{array}$ \\
\hline $\begin{array}{l}47 \text { Children of LWP } \\
\text { vs } \\
\text { 94 LWP ( } 47 \text { pairs) }\end{array}$ & $\begin{array}{l}159 \\
141\end{array}$ & 0.0005 & $\begin{array}{l}\text { Exccss whorls in children, com- } \\
\text { pared with low whorl parents. }\end{array}$ \\
\hline $\begin{array}{l}32 \text { Children of HWP } \\
\text { vs } \\
500 \text { Control subjects }\end{array}$ & $\begin{array}{r}200 \\
1,287\end{array}$ & 0.0005 & $\begin{array}{l}\text { Excess whorls in children, com- } \\
\text { pared with control subjects. }\end{array}$ \\
\hline $\begin{array}{l}47 \text { Children of LWP } \\
\text { vs } \\
500 \text { Control subjects }\end{array}$ & 1,287 & 0.0005 & $\begin{array}{l}\text { Excess whorls in children, com- } \\
\text { pared with control subjects. }\end{array}$ \\
\hline
\end{tabular}


in both these comparisons (Table IV) the rubellaaffected children have significantly more whorl patterns than their parents. Similarly, when the rubella children of HWP and LWP are compared separately with control subjects, 'a significant excess of whorls is found in the children; i.e., even the rubella-affected children of LWP have more whorls than the control subjects.

\section{Discussion}

Although the dermatoglyphic anomalies in patients with rubella embryopathy have been recognized for some years, there has been no attempt previously to determine the relative contributions made to these anomalies by genetic and viral factors. This study of 120 patients confirms that the dermatoglyphics of patients with congenital rubella show a greatly increased incidence of digital whorl patterns, and examination of the parents indicates that both genetic and teratogenic factors contribute towards this high whorl count. Two further points of interest which emerge are the accentuated sex differences in congenital rubella patients compared with controls, and the raised frequency of whorl patterns in the fathers of the patients.

Demonstration of the dual influence of genome and environment on the development of digital patterns in our patients is not unexpected. The high heritability of dermatoglyphic patterns is well recognized [3] and is illustrated by the strong correlation between parents and their children and between identical twins. Against this underlying genetic influence however, comparison of patients with their parents provides evidence that the major determinant of digital whorl patterns in rubella embryopathy is of environmental rather than of genetic origin.

Sex differences in digital pattern type are likewise well known, males tending to have more whorl patterns and less arches than females [3, 4]. The marked accentuation of normal sex differences in our present group of patients has been noted previously in adults with rubella embryopathy [12] and is yet another example of the influence of sex on the response to various pathogens. Sexual variation in susceptibility to rubella embryopathy was suggested when male patients were found to have significantly greater growth retardation and duration of persisting postnatal infection $[6,7]$ and a recent review (unpublished) [13] of 243 unselected children with congenital rubella (129 males) showed a male to female ratio of $113: 100$. This figure is high when compared with an Australian male to female average ratio at birth of 105.4:100 (1966-1970), and may reflect male susceptibility to in utero rubella infection.

The implications of the raised whorl frequency in the fathers of congenital rubella patients are not immediately obvious. Such a phenomenon may have arisen by chance, but other evidence makes this unlikely; similar findings have been made in small groups of fathers whose children suffered in utero cytomegalovirus infection $[10,14]$. As in congenital rubella, children with congenital cytomegalovirus have an increased whorl frequency. The evidence in these two diseases points to selection of fathers with a raised whorl frequency; such selection, however, is difficult to reconcile with intrauterine infection syndromes in which it is the pregnant mother who is selected by the virus concerned. A possible explanation is that selection occurs at the fetal level; i.e., those fetuses with a paternal genotype favoring whorl formation are more susceptible to the infection and are more likely to exhibit both raised whorl frequency and clinically significant embryopathy.

The mechanism of digital pattern morphogenesis proposed by Mulvihill and Smith [8] embodies the principle that dermal ridges develop at right angles to the plane of growth forces and that the patterns formed over the fetal digital pads reflect the height and symmetry of the pads; whorls reflect high pads and arches reflect low pads. In congenital rubella, which is characterized by growth retardation and developmental arrest, it would be reasonable to expect some hypoplasia of digital pads with a consequent predominance of loop or arch patterns, but such patients actually exhibit a raised whorl frequency. This paradox can perhaps be explained by examination of the relation between the time of fetal pad formation and the time of ridge formation: a relation which is also important in pattern determination. According to the data of Mulvihill and Smith [8], pad formation is normally at its peak at about the 7th fetal week, this period being followed by pad regression. Ridge formation occurs from the 13th week and hence normally coincides with the period of pad regression; the tendency in this normal situation would be to form patterns other than whorls. However, should an intrauterine virus infection such as rubella delay the development or the regression of fetal pads so that their growth peak coincides with the time of dermal ridge formation, a raised frequency of whorl patterns 
might result. Genetic factors which alter the temporal relationship between pad and ridge formation may also explain the raised whorl frequency in the children and in their fathers. Thus both genetic factors and the viral influence may account for the very high whorl frequency in the patients.

\section{Summary}

The dermatoglyphics of patients with rubella embryopathy have a significantly raised whorl pattern frequency. Examination of the parents of such patients shows that although genetic factors influence the development of whorl patterns in the patients, teratogenic factors appear to dominate.

\section{References and Notes}

I. Achs, R., Harper, R. G., And Siegel, M.: Unusual dermatoglyphic findings associated with rubella embryopathy. New Engl. J. Med., 274: 148 (1966).

2. Alter, M., and Schulenberg, R.: Dermatoglyphics in the rubella syndrome. J. Amer. Med. Ass., 197: 685 (1966).

3. Cummins, H., And Midlo, C.: Finger Prints, Palms and Soles: An Introduction to Dermatoglyphics. (Dover Publications, New York, 1961).

4. Holt, S. B.: The Genetics of Dermal Ridges. (Charles G Thomas, Publisher, Springfield, Ill., 1968).
5. Menser, M. A., Dods, L., and Harley, J. D.: A twenty-fiveyear follow-up of congenital rubella. Lancet, ii: 1347 (1967).

6. MichaeLs, R. H.: Immunologic aspects of congenital rubella. Pediatrics, 43: 339 (1969).

7. Mrchaels, R. H., AND Kenny, F. M.: Postnatal growth retardation in congenital rubella. Pediatrics, 43: 251 (1969).

8. Mulvihild, J. J., ANd SMith, D. W.: The genesis of dermatoglyphics. J. Pediat., 75: 579 (1969).

9. Purvis-Smirh, S. G.: Finger and palm printing techniques for the clinician. Med. J. Aust., 2: 189 (1969).

10. Purvis-Smith, S. G., Hayes, K., and Menser, M. A.: Dermatoglyphics in children with prenatal cytomegalovirus infection. Lancet, $i i$ : 976 (1972).

11. Purvis-Smith, S. G., Howard, P. R., And Menser, M. A.: Dermatoglyphic defects and rubella teratogenesis. J. Amer. Med. Ass., 209: 1865 (1969).

12. Purvis-Smith, S. G., And Menser, M. A.: Dermatoglyphics in adults with congenital rubella. Lancet, $i i$ : 141 (1968).

13. Purvis-Smith, S. G. AND Menser, M. A.: Unpublished data (1973).

14. Wright, H. T., Parker, C. E., and Mavalwala, J.: Unusual dermatoglyphic findings associated with cytomegalic inclusion disease of infancy-A first report and practical review. Calif. Med., 116: 14 (1972).

15. This research was supported by a grant from the National Health and Medical Research Council of Australia.

16. Requests for reprints should be addressed to: S. G. PurvisSmrrh, B. Sc., Children's Medical Research Foundation, P. O. Box 61, Camperdown, N.S.W. 2050, Australia.

17. Accepted for publication December 19, 1972. 